\title{
IL12A wt Allele
}

National Cancer Institute

\section{Source}

National Cancer Institute. IL12A wt Allele. NCI Thesaurus. Code C52042.

Human IL12A wild-type allele is located within 3p12-q13.2 and is approximately $7 \mathrm{~kb}$ in length. This allele, which encodes interleukin-12 alpha chain protein, is involved in promoting the growth of both T cells and natural killer cells. It also plays a role in the differentiation of both Th1 and Th2 cells. 